\title{
Zebra Mussel Demography and Modeling: Preliminary Analysis of Population Data from Upper Midwest Rivers
}

by Reşit Akçakaya, Patrick Baker

Applied Biomathematics 100 North Country Road

Setauket, NY 11733

Final report

Approved for public release; distribution is unlimited

Prepared for U.S. Army Corps of Engineers

Washington, DC 20314-1000

Under Contract No. DACW39-97-M-1558

Monitored by U.S. Army Engineer Waterways Experiment Station 3909 Halls Ferry Road, Vicksburg, MS 39180 